\title{
Effects of plant density and nitrogen fertilization in winter wheat (Triticum aestivum L.). 1. Production pattern and grain yield
}

\section{J. Ellen}

Department of Field Crops and Grassland Science, Agricultural University, Haarweg 333, 6709 RZ, Wageningen, Netherlands

Received 23 December 1985; accepted 26 February 1987

Key words: winter wheat, yield components, leaf area index, leaf area duration, specific leaf weight, shoot weight, nitrogen, split dressing, nitrogen economy, water-soluble carbohydrates

\begin{abstract}
The effects of plant density and nitrogen dressing on shoot development, shoot weight and yield components were investigated in winter wheat.

Delaying the first $\mathrm{N}$ dressing resulted in fewer shoots per plant at both low and high plant densities. Grain number per ear went up, but grain number per $\mathrm{m}^{2}$ was hardly affected. The 1000-grain weight decreased the longer the $\mathrm{N}$ dressing was delayed. Delaying the first $\mathbf{N}$ dressing led to a smaller leaf area per plant, per shoot and per $\mathrm{m}^{2}$. Higher shoot weight before anthesis correlated better with final grain weight than with grain number ( $r=0.74$ and 0.66 , respectively). The main stems and tillers not only differed in development and growth rate but also in leaf area, specific leaf weight and dry matter content of the ear.

$\mathrm{N}$ uptake was more rapid the longer the first $\mathrm{N}$ dressing was delayed. Late application of the first $\mathbf{N}$ dressing, however, limited the nitrogen efficiency in dry matter production, because the biomass of the crop had already been fixed to a certain extent. On the other hand, the $\mathrm{N}$ content of the vegetative plant parts and of the grains was considerably boosted. In the vegetative plant parts the increase was greater at low plant density than at high plant density. In the grains this increase was less clear.

The content and amount of water-soluble carbohydrates in stems, leaves and chaff were, on average, lower at the low plant density. This phenomenon arose during the last stage of the grain-filling period. Differences in the time at which the first $\mathrm{N}$ dressing was given resulted in different levels and different amounts of water-soluble carbohydrates at ripening.
\end{abstract}




\section{J. ELLEN}

\section{Introduction}

The effects of plant density on shoot initiation and development have been described by various authors. Increasing the number of plants per $\mathrm{m}^{2}$ has generally been found to lead to fewer shoots per plant, lower grain number per ear and lower weight of individual grains (e.g. Darwinkel, 1978; Puckridge \& Donald, 1967). Because of the great compensating ability of tillering wheat cultivars, grain yields per unit area are generally not strongly affected. It is hard to attribute the differences to any specific yield component. Nevertheless, a good grain yield always requires a sufficient number of grains per $\mathrm{m}^{2}$. This component correlates strongly with yield (Darwinkel, 1978; Ellen \& Spiertz, 1980; McLaren, 1981; and others). Compensation for a low grain number by means of a higher 1000 -grain weight is genetically restricted (Sofield et al., 1977).

For the optimalization of the grain yield not only plant density must be controlled: nitrogen fertilization and a concomitant supply of water are also of the greatest importance. This is also shown by the influence of these latter two factors on leaf area, rate of production (Ellen \& Spiertz, 1975) and leaf area duration (Ellen \& Spiertz, 1980). Splitting the total $N$ dressing into several applications results in a more controllable crop growth and thus mostly in a higher grain yield (Dilz, 1969).

The number of spikelets per ear and the number of florets per spikelet can, to a certain extent, be influenced by nitrogen application in the early developmental stages of crop plants (Langer, 1979; Whingwiri \& Kemp, 1980). Besides, the development of the shoot and the ear in the pre-anthesis phase depends on the duration of solar radiation received (Fischer \& Stockman, 1980) and a sufficient supply of water (Oosterhuis \& Cartwright, 1983).

It is not clear whether delaying the first $\mathrm{N}$ dressing and/or providing a $\mathrm{N}$ supply at later stages of development will affect the morphological and physiological structure of the crop and consequently its yield. A delay of the first $\mathrm{N}$ dressing may result in less tillering and thus reduce intershoot competition. Dressing with $\mathrm{N}$ later in the season may induce the existing tillers to gain in shoot weight, to develop greater ears and to increase grain yield. To investigate this, an experiment was set up, in which the effect of $\mathbf{N}$ fertilization on the structure of plants and shoots was observed under two densities. A subsequent paper will describe the consequences of this effect to the susceptibility of the plants for the fungi Gerlachia nivalis and Fusarium spp.

\section{Methods}

The experiment was laid out side by side in a randomized block design with 4 replicates. The soil was a fertile clay in the Flevopolder and the preceding crop was potato. Before sowing, $325 \mathrm{~kg}$ superphosphate $\left(45 \% \mathrm{P}_{2} \mathrm{O}_{5}\right)$ was applied. Potassium was not given, because the soil already contained this element sufficiently. The content of $\mathrm{NO}_{3}-\mathrm{N}$, as measured in mid-April at a depth between $0-100 \mathrm{~cm}$ on bare places in the experimental plot, was $60 \mathrm{~kg} / \mathrm{ha}$. During the growing season it gradually in- 
creased, attaining $140 \mathrm{~kg} / \mathrm{ha}$ by mid-August.

The winter wheat cultivar Arminda was sown on 8 October 1979 at seed rates of 45 (S1) and 125 (S2) $\mathrm{kg}$ per ha. The rows were $15 \mathrm{~cm}$ apart.

The total $\mathrm{N}$ fertilization was fixed at $140 \mathrm{~kg} / \mathrm{ha}$ and supplied according to the following scheme (the stages in this paper conform with the scale of Zadoks et al., 1974).

$\begin{array}{llllllll}\text { Growth stage: } & 22 & 27 & 30 & 31 & 32 & 37 & 45 \\ \text { Date of application } & 29 / 3 & 10 / 4 & 21 / 4 & 6 / 5 & 13 / 5 & 23 / 5 & 6 / 6 \\ \text { N1 } & 60 & - & - & - & - & - & 80 \\ \text { N2 } & - & 60 & - & - & - & - & 80 \\ \text { N3 } & - & - & 60 & - & - & - & 80 \\ \text { N4 } & - & - & - & 60 & - & - & 80 \\ \text { N5 } & - & - & - & - & 60 & - & 80 \\ \text { N6 } & - & - & - & - & - & 60 & 80\end{array}$

Weeds, diseases and aphids were adequately controlled by herbicides and pesticides; to lower the risks for lodging, chlormequat (CCC) was sprayed.

During the growing season, the growth of the crop was followed by sub-sampling on 10/4,21/4, 6/5 and $27 / 5$ (i.e. before anthesis) and on 17/6, 1/7, 15/7 and 29/7 (i.e. after anthesis). The sampled area per plot was 4 rows of $50 \mathrm{~cm}$ length on each date. Green leaf-blade area on main stems and tillers was measured; fresh and dry matter weights were determined and the shoots, ears and grains were counted. Samples were dried for 24 hours at $70{ }^{\circ} \mathrm{C}$. The replications were pooled for chemical analyses (N-Kjeldahl and/or water-soluble carbohydrates; for method, see Spiertz, 1977).

To ascertain the number of shoots per $\mathrm{m}^{2}$, the grain weight per ear and the 1000 grain weight, two rows each $1 \mathrm{~m}$ long were harvested from each mature plot on 12 August. Per plot $60 \mathrm{~m}^{2}$ was combine harvested on 15 August, so that the grain yield per ha could be assessed. Per plot, about $2 \mathrm{~kg}$ of seed was reserved for testing of disease incidence.

The weather during the 1980 growing season was rather cool with temperatures well over $1{ }^{\circ} \mathrm{C}$ below the mean day temperature for the period 1931-1960. December 1979 was wet, but the amount of precipitation was normal from January up to mid-April. The 3rd decade in April and the first 2 decades in May were extremely dry, whereas June and July were very wet. Radiation was high in April and May but low in March, June and July.

\section{Results}

\section{Yield and yield components}

The number of plants per $\mathrm{m}^{2}$, counted on 31 March, were 116 and 311 for $\mathrm{S} 1$ and S2 respectively. Between S1 and S2 there was a difference in both total dry matter yield of aerial plant parts and grain dry matter yield (Table 1). These differences, averaged over the $6 \mathrm{~N}$ treatments, were chiefly caused by a larger number of shoots per $\mathrm{m}^{2}$. With sowing rate S1, grain number per ear was higher than in S2. Because 


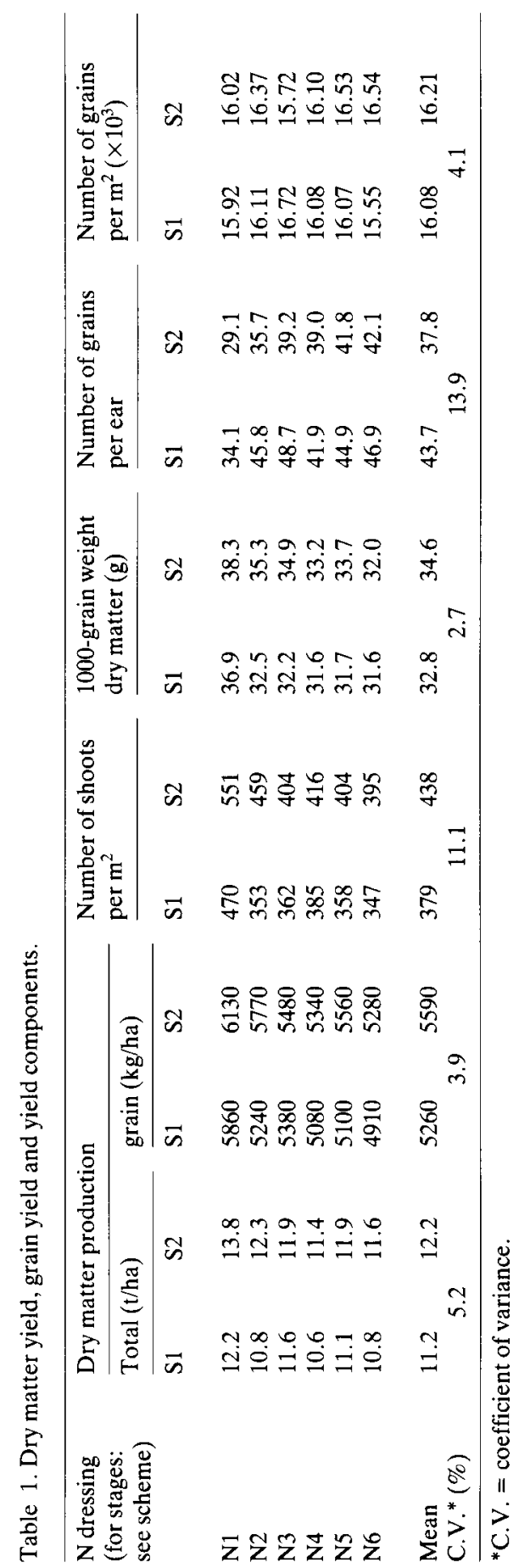


there were more shoots per $\mathrm{m}^{2}$ in $\mathrm{S} 2$, the number of grains $/ \mathrm{m}^{2}$ was about similar for both seed rates.

A delay of the first $\mathrm{N}$ dressing until growth stage 37 resulted in a lower total dry matter yield in both S1 and S2. Similarly, the total grain dry matter yield also fell to a lower level. The lower total dry matter yield and the lower grain dry matter yield were mainly caused by fewer shoots per $\mathrm{m}^{2}$. The greatest effect of fertilizing strategy on number of shoots was observed in N1 (S1 and S2); there were considerable more shoots $/ \mathrm{m}^{2}$ than in N2 through N6 (S1 and S2). The latter can be caused by means of the low rainfall during stem elongation, leading to inactivity of nitrogen.

The 1000-grain weight measured after combine harvesting was lower the later the first $\mathrm{N}$ dressing was applied. The 1000-grain weight in S2 was somewhat higher than in $\mathrm{S} 1$.

The number of grains per ear behaved adversely to 1000 -grain weight. A greater number of grains per ear led to a lower 1000 -grain weight $(r=-0.91 ; P \leqslant 0.001)$. In N1 fewer grains per ear were found than in N2 through N6. S1 and S2 seemed to be differently affected; in $\mathrm{S} 1$ the increase was rather irregular, whereas in $\mathrm{S} 2$ a regular increase in grain number was observed with a delay of the first $\mathrm{N}$ dressing.

The number of grains per $\mathrm{m}^{2}$, counted after combine harvesting did not vary greatly in response to delaying the first $\mathrm{N}$ dressing. In both $\mathrm{S} 1$ and $\mathrm{S} 2$ the average was approximately 16000 grains per $\mathrm{m}^{2}$.

\section{Leaf area, leaf area duration and dry matter weight per unit leaf area}

A delay of the first $\mathrm{N}$ dressing not only led to a smaller leaf area but also to a slower development of leaf area per plant (Fig. 1A). At the end of anthesis (17/6) the values found in $\mathrm{N} 1$ and $\mathrm{N} 6$ were $380 \mathrm{~cm}^{2}$ and $275 \mathrm{~cm}^{2}$ per plant for $\mathrm{S} 1$, respectively, and $180 \mathrm{~cm}^{2}$ and $145 \mathrm{~cm}^{2}$ per plant for $\mathrm{N} 1$ and $\mathrm{N} 6$ in $\mathrm{S} 2$.

The differences in leaf area per shoot between main stem (MS) and tillers (T1, $\mathrm{T} 2, \mathrm{~T} 3$ ), measured as the average value for all $\mathrm{N}$ dressings could clearly be demonstrated (Fig. 1B). On 17/6 the respective values for main stem and second tillers were $75 \mathrm{~cm}^{2}$ and $58 \mathrm{~cm}^{2}$ for $S 1$ and $64 \mathrm{~cm}^{2}$ and $35 \mathrm{~cm}^{2}$ for $S 2$.

The leaf area index (LAI) can be obtained by multiplying the average number of plants per $\mathrm{m}^{2}$ by the leaf area per plant. It was found that the more plants there are per $\mathrm{m}^{2}$, the faster a closed foliage $(\mathrm{LAI} \approx 3$ ) is attained. It was also found that a delay of the first $\mathrm{N}$ dressing limits the leaf area per plant as well as per $\mathrm{m}^{2}$.

The size and duration of the assimilating green leaves can be expressed in the parameter LAD (leaf area duration). This is the integral of leaf area in time. When calculating LAD expressed in leaf-weeks $\times \mathrm{m}^{2}$, values of 39 and 53 were found for $\mathrm{S} 1$ and $\mathrm{S} 2$ as averaged over the $\mathrm{N}$ dressings. Averaged over the $\mathrm{N}$ dressings, LAD per plant, expressed in leaf-weeks $\times \mathrm{dm}^{2}$, was 34 (S1) and 17 (S2). Averaged over the $\mathrm{N}$ treatments, LAD in leaf-weeks for the shoots, expressed in leaf-weeks $\times$ $\mathrm{cm}^{2}$, ranged from 80 to 65 for the main stem through the second tiller in S1 and from 72 to 30 for $S 2$. For simplification, these latter two integrals $\left(\mathrm{dm}^{2} ; \mathrm{cm}^{2}\right)$ are called LAD.

The growth of the grains started at the time that the LAI started to decrease (about one week after flowering). Per unit leaf area a difference in productivity 

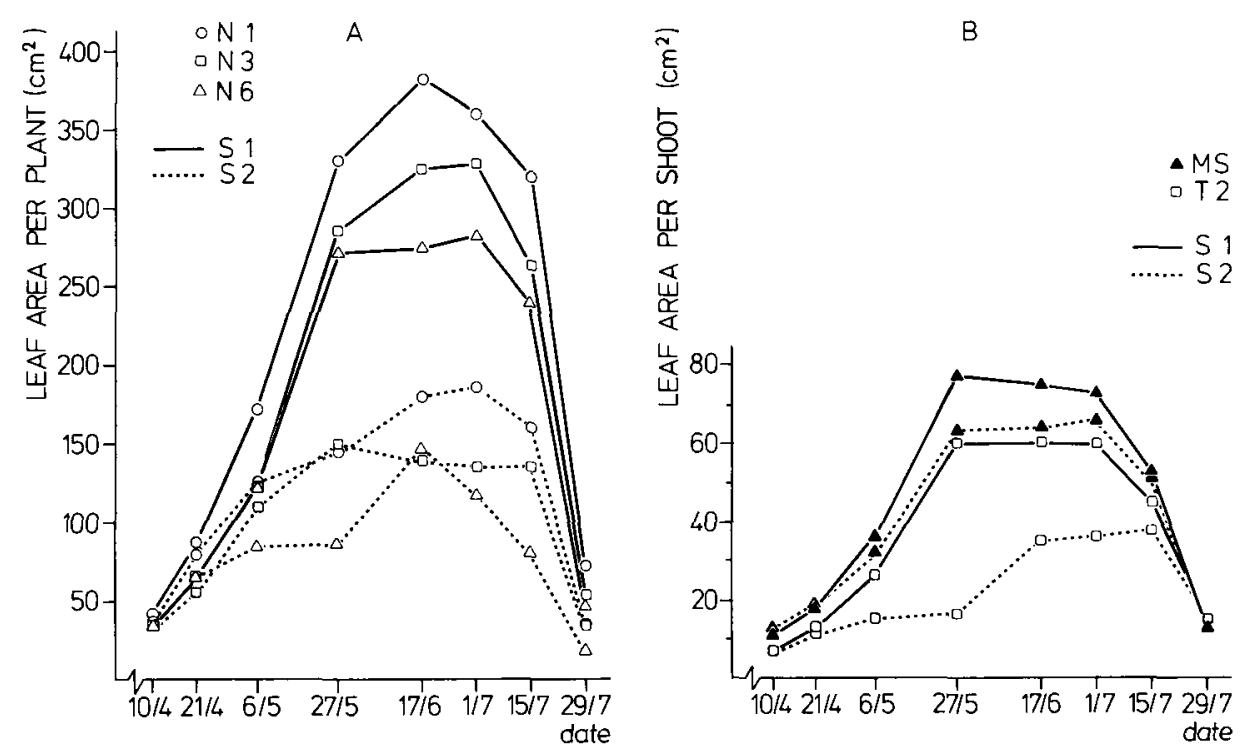

Fig. 1. Leaf area per plant (A) for S1 (-) and S2 (---) and per shoot (B). Mean of all N dressings for main stem (MS) and tillers (T2).

could be deduced. Averaged over the $\mathrm{N}$ dressings, the grain dry matter yields for $\mathrm{S} 1$ and $\mathrm{S} 2$ were $135 \mathrm{~g}$ and $106 \mathrm{~g}$ per $\mathrm{m}^{2}$ per leaf-week, respectively.

In the period from $27 / 5$ to $15 / 7$ the mean specific leaf weight (SLW) was 5.7 $\mathrm{mg} / \mathrm{cm}^{2}$ for S1 and $5.3 \mathrm{mg} / \mathrm{cm}^{2}$ for S2. There was also a difference between main stems and tillers. The higher the rank of the shoots, the lower the specific leaf weight. At $17 / 6$ leaves of the main stems (MS) achieved in S1 a SLW of $6.2 \mathrm{mg} / \mathrm{cm}^{2}$ and the leaves of the second tillers (T2) $5.9 \mathrm{mg} / \mathrm{cm}^{2}$. For S2 the corresponding values were 6.0 and $5.4 \mathrm{mg} / \mathrm{cm}^{2}$. The decrease of SLW corresponded with the decrease in LAI as found in Fig. 1.

Relationship between the leaf weight and leaf area before anthesis and the yield components

Individual shoot weight before anthesis (27/5) and its final grain yield (29/7) showed a close correlation. Fig. 2 presents the increase in the total amount of dry matter and the grain development for the main stems and tillers in S1, for both the early (N1) and the late (N6) first dressings; similar data were found for the high seed rate S2. A higher shoot weight before anthesis correlated more strongly with high grain yield per ear $(r=0.74 ; P \leqslant 0.001)$ than with greater number of grains per ear $(r=$ $0.66 ; P \leqslant 0.001)$. It was found that a higher growth rate per shoot before anthesis also caused a higher growth rate of grains per ear $(r=0.71 ; P \leqslant 0.001)$.

For both seed rates a good relationship was found between leaf area per shoot (on 27/5) and the grain number per ear (on 29/7), and between leaf area per shoot 

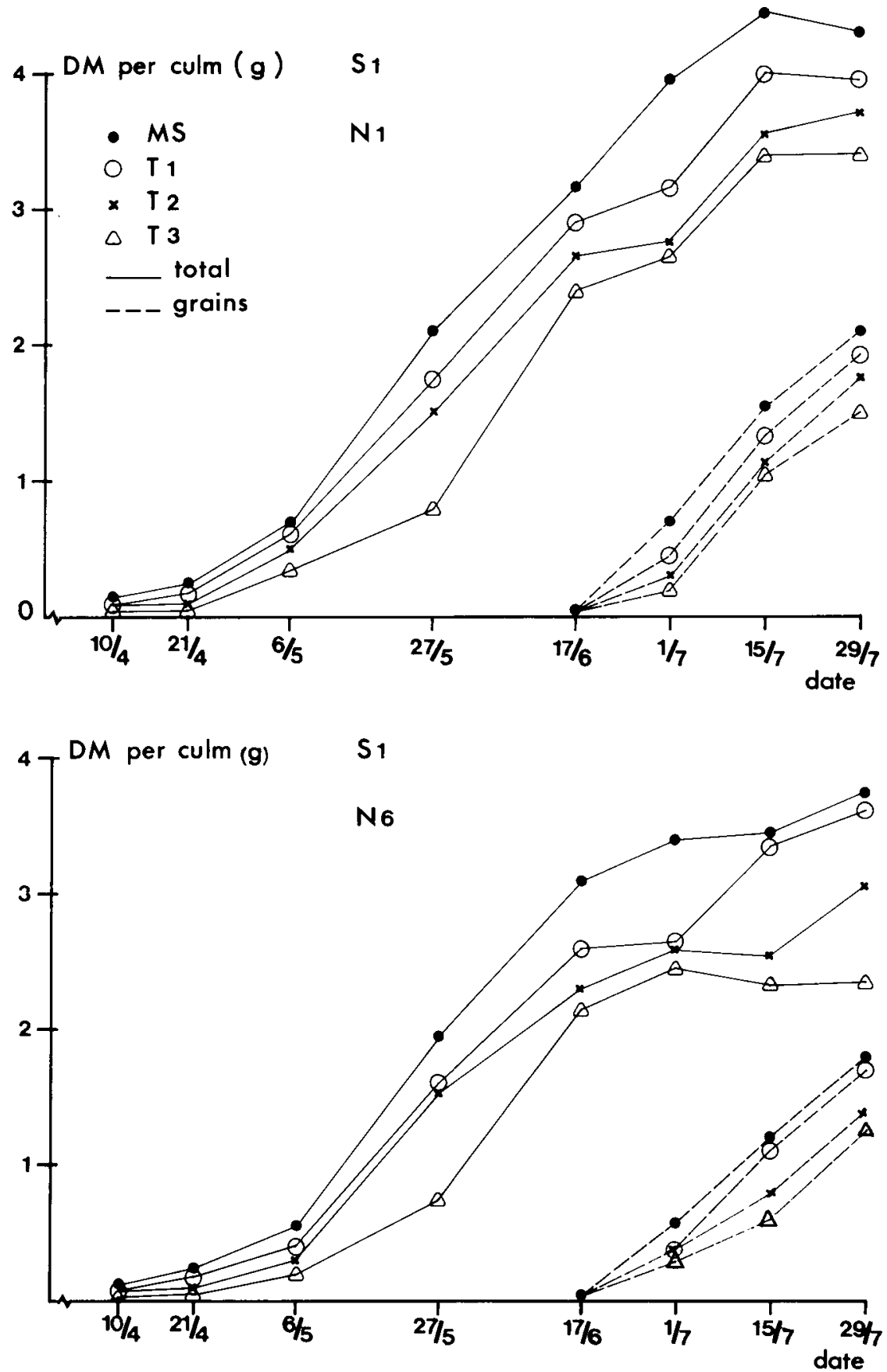

Fig. 2. Course of shoot and grain dry weight of different tillers at 2 plant densities and early (N1) and late (N6) first $\mathrm{N}$ dressings. 
(on 27/5) and the grain yield per ear (on 29/7): $r=0.65$ and 0.77 respectively $(P \leqslant$ 0.001 for both).

\section{Influence of time of dressing on shoot weight}

A delay of the first $\mathrm{N}$ dressing adversely affected the increase in weight of the individual shoots. In the S1N1 treatment the increase in the period from $21 / 4$ to $1 / 7$, which coincides with an almost linear growth rate of the shoots, was 52, 42, 38 and $36 \mathrm{mg} /$ day for the main stems and the 1st, 2nd and 3rd tillers, but only 45, 34, 34 and $33 \mathrm{mg} /$ day for the corresponding shoots in the S1N6 treatment. For S2N1, a growth rate of 43,34 and $25 \mathrm{mg} /$ day was measured for the main stems, the 1st and $2 \mathrm{nd}$ tillers, respectively, and in the S2N6 treatment the corresponding values for the main stems and first tillers were 38 and $30 \mathrm{mg} /$ day (most plants in S2 did not develop a $2 \mathrm{nd}$ tiller). In the other plots the values were generally intermediate.

\section{Dry matter content of the ears}

Fig. 3 presents the course of the moisture content of the ears for main stems and tillers as averaged over the $\mathrm{N}$ dressings for $\mathrm{S} 1$. In S2 the moisture content of the ears was on average about $1.2 \%$ lower for main stems and tillers during grain filling. The advantage in ranking order of the shoots for moisture content continues up to the final harvest. Fig. 3 reinforces the observation that the tillers of a higher order began to develop later in the season and keep green longer.

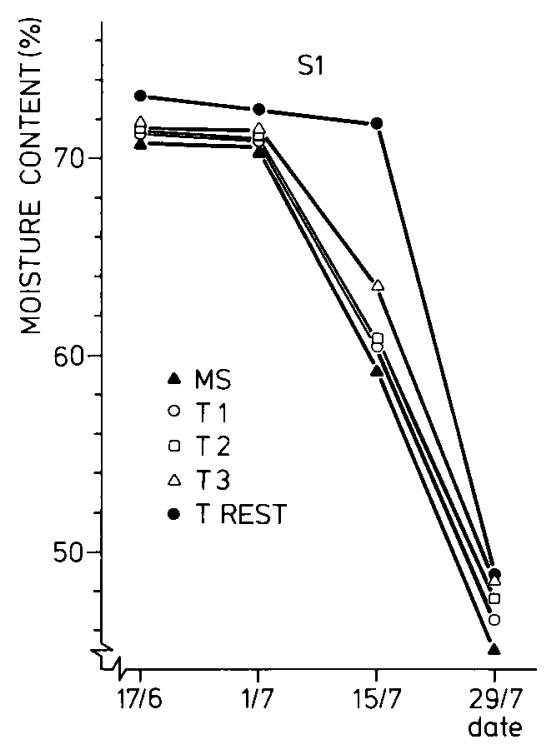

Fig. 3. Decrease of moisture content in the ears of main stem and tillers. Average of all $\mathrm{N}$ dressings. 


\section{Nitrogen economy}

The time of nitrogen dressing affected the nitrogen content in the leaves and stems (including the chaff). The amount of mineral supply of nitrogen in the soil also plays a role. A late application of the first $\mathrm{N}$ dressing increased the nitrogen content, because the $\mathrm{N}$ uptake was more boosted than the dry matter production. This was mainly expressed in the period from mid-June to mid-July. In that time the differences in nitrogen content between $\mathrm{N}$ treatments were greater in S1 than in S2, ranging from about $0.90 \%$ to about $1.25 \%$ in $\mathrm{S} 1$ and from about $0.82 \%$ to about
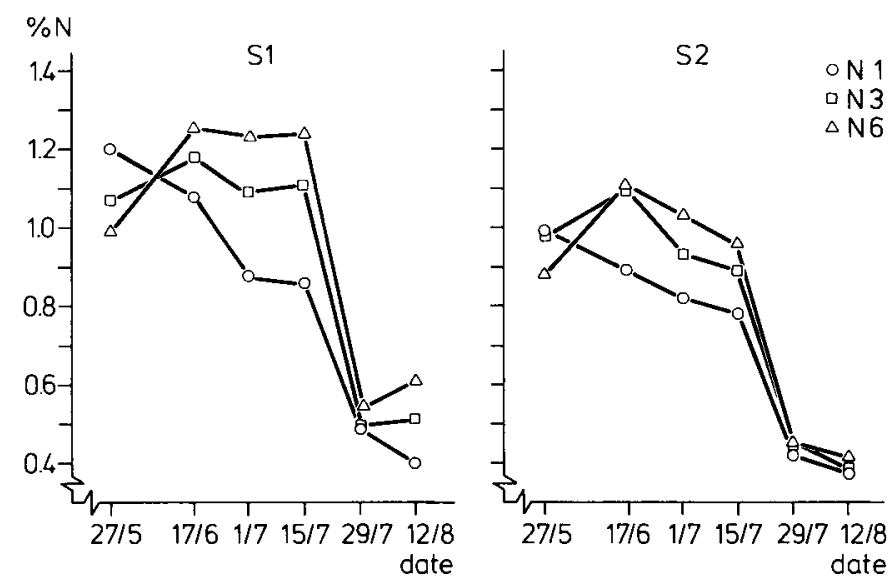

Fig. 4. Effects of different strategies of nitrogen dressings on nitrogen percentages in leaves plus stems (and chaff) at 2 plant densities.
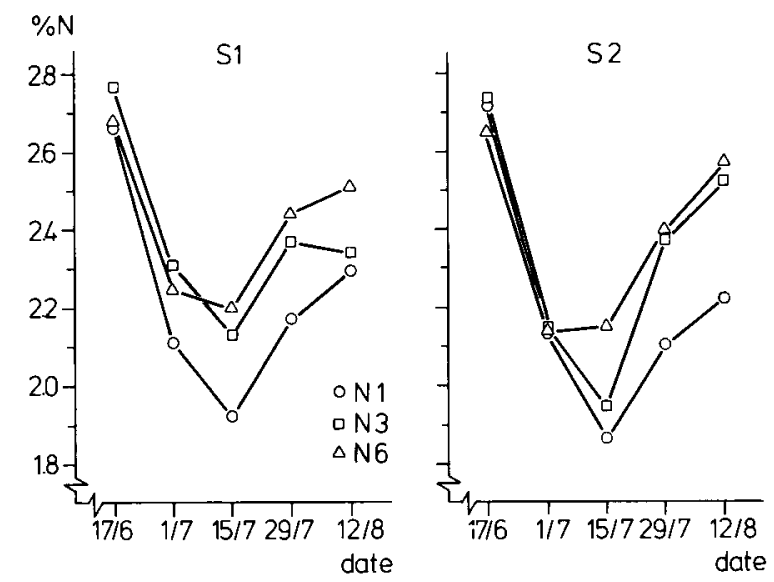

Fig. 5. Effects of different strategies of nitrogen dressings on nitrogen percentages in the grains at 2 plant densities. 


\section{J. ELLEN}

$1.00 \%$ in S2 (Fig. 4). Averaged over the $\mathrm{N}$ dressings, the nitrogen content decreased after mid-July as a result of the reallocation of the nitrogen from leaves and straw to the grains; it is possible that some $\mathrm{N}$ was lost by leaching, caused by the high precipitation. For $\mathrm{S} 2$ this process resulted in a somewhat lower nitrogen content than for S1 (Fig. 4). The ripening in S1 proceeded at a slower rate than in S2. In the grains, nitrogen contents decreased from 17/6 until 15/7; afterwards these contents increased again. The decrease in $\mathrm{N}$ content (Fig. 5) coincided with a sharp increase in grain weight. The date of application of the first $\mathrm{N}$ dressing influenced the nitrogen content in the grains; a delay of the first $\mathrm{N}$ dressing increased the $\mathrm{N}$ content. At $15 / 7$ the $\mathrm{N}$ contents ranged from $1.90 \%$ to $2.20 \%$ for $\mathrm{S} 1$ and from $1.86 \%$ to $2.18 \%$ for S2. During grain filling an amount of $\mathrm{N}$ shall be taken up due to the high mineralization in the soil. The nitrogen contents in the grains increased after $15 / 7$ with about $0.35 \%$.

\section{Nitrogen uptake and distribution}

Delaying the first $\mathrm{N}$ dressings until later stages of development did not appear to have great repercussions on the total $\mathrm{N}$ uptake, probably caused by low rainfall during the first half of May. Shortly after the latest dressing (N6) had been applied, N
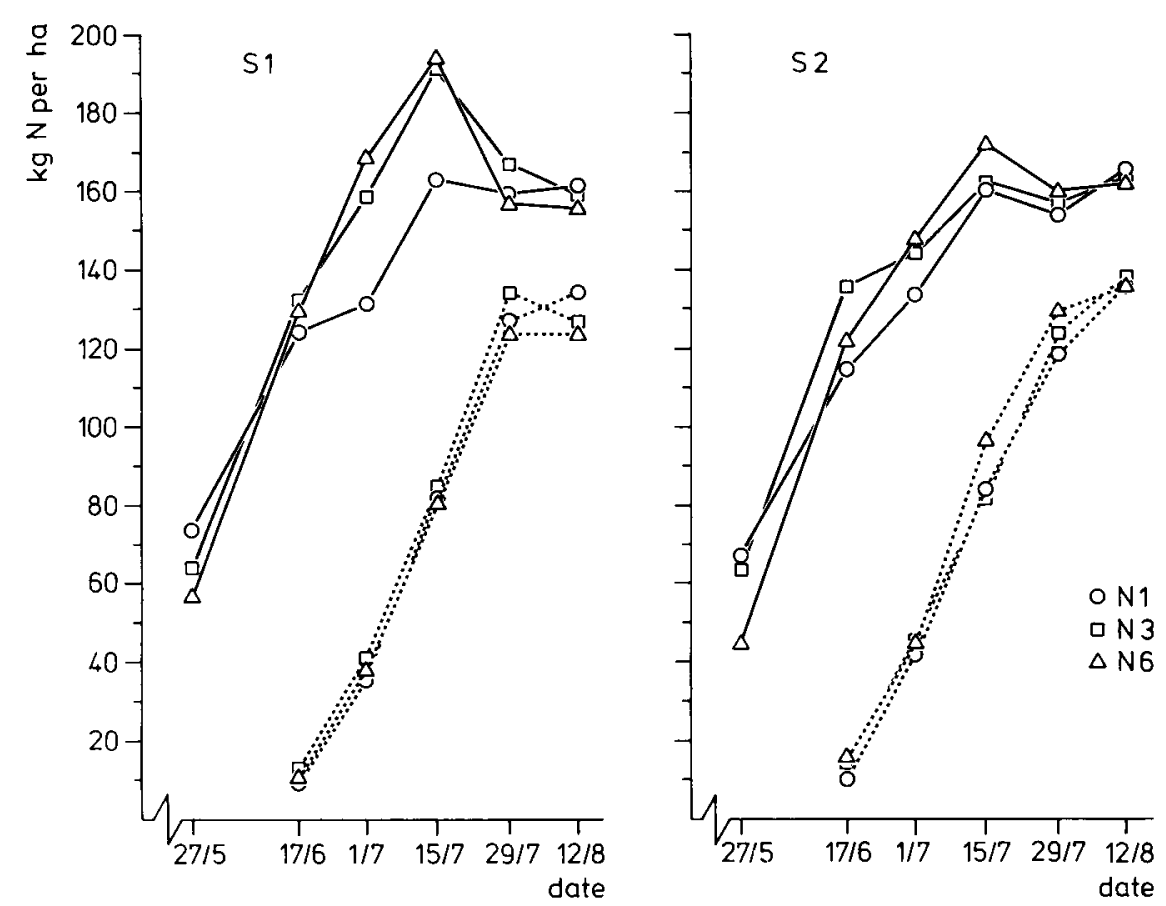

Fig. 6. Uptake of nitrogen (N); total (-) and in the grains (---) at 2 plant densities. 
Table 2. $\mathbf{N}$ uptake in $\mathrm{mg}$ per shoot (21/8/80).

\begin{tabular}{|c|c|c|c|c|c|c|}
\hline & $\mathrm{N} 1$ & N2 & N3 & N4 & N5 & N6 \\
\hline S1 & 35.2 & 46.3 & 48.2 & 44.2 & 45.9 & 45.2 \\
\hline S2 & 30.7 & 39.6 & 39.2 & 41.9 & 38.2 & 39.1 \\
\hline
\end{tabular}

invariably accumulated rapidly by the plants. The greatest differences in $\mathrm{N}$ uptake, i.e. those between the first and the late dressings were found in crop samples taken in July (Fig. 6). The difference in uptake of N in July between N1 and N6 was $35 \mathrm{~kg}$ $\mathrm{N} / \mathrm{ha}$ in $\mathrm{S} 1$ and $15 \mathrm{~kg} \mathrm{~N} / \mathrm{ha}$ in S2. Delayed first dressings resulted in an increase in vigour of the shoots at an advanced stage of development.

The $\mathrm{N}$ uptake in mg per shoot varied (Table 2). Delaying the first $\mathrm{N}$ applications resulted in an increased $\mathrm{N}$ uptake per shoot. When number of shoots per $\mathrm{m}^{2}$ was plotted against amount of nitrogen per shoot, the correlation appeared to be -0.94 $(P \leqslant 0.001)$.

Notwithstanding the large variation in the amounts of nitrogen in stems, chaff and leaves, a very stable increase in nitrogen was observed in the grains (Fig. 6). Averaged over all the $\mathrm{N}$ dressings, the total $\mathrm{N}$ uptake in the grains amounted to about $130 \mathrm{~kg} / \mathrm{ha}$. Only small differences were observed between the different strategies of $\mathrm{N}$ application. For the linear course from $17 / 6$ to $29 / 7$ this means an increase in nitrogen of over $3 \mathrm{~kg} / \mathrm{ha}$ per day, on an average.
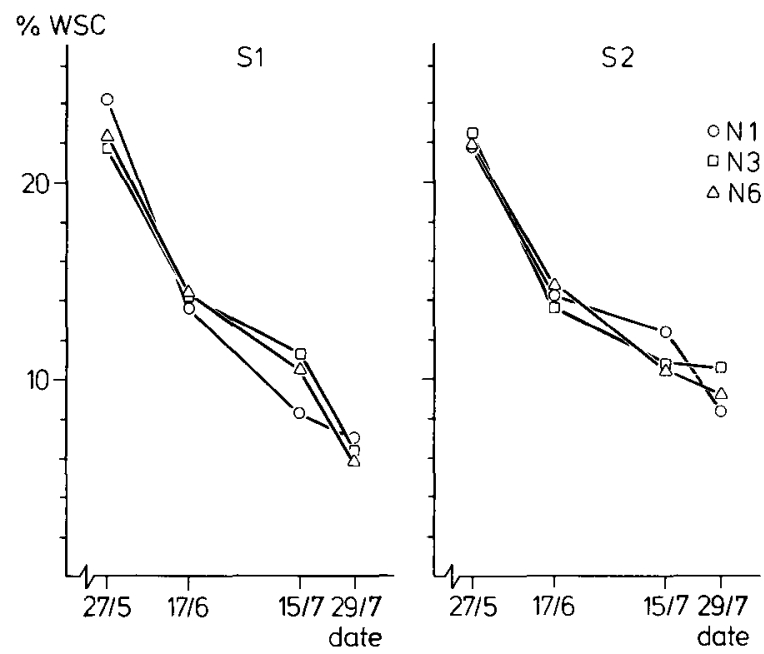

Fig. 7. The water-soluble carbohydrate content in leaves, stems (and chaff) from growth stage 39 until ripening at different strategies of nitrogen dressings. 


\section{J. ELLEN}

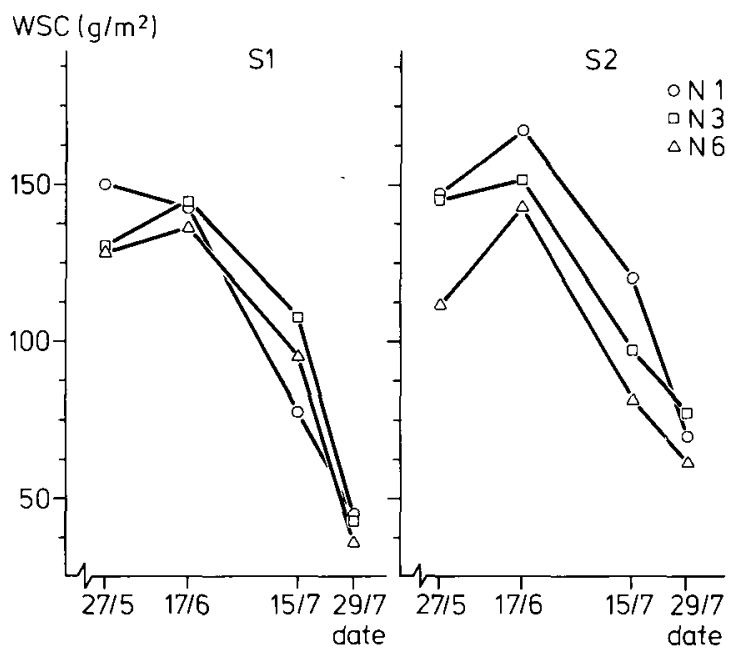

Fig. 8. The water-soluble carbohydrate production in leaves, stems (and chaff) from growth stage 39 until ripening at 2 plant densities and different strategies of nitrogen dressings.

Water-soluble carbohydrates in the vegetative plant parts

Carbohydrates are very important for the development of ears and grains. When conditions for growth are adequate (ample water and nutrients; healthy plants) much radiation will lead to a high reserve of water-soluble carbohydrates (WSC). A large supply of WSC may be very important for grain initiation and the onset of grain filling.

A delay of $\mathrm{N}$ application caused a lower WSC content at 27/5 in S1 but not in S2 (Fig. 7). At the end of anthesis (17/6) and during the post-anthesis stage the differences in WSC content were small. It was remarkable that in all treatments the WSC content had already started to decrease from GS 39 (27/5), probably caused by low radiation in the last week of May, in June and in July. The difference in WSC content between the various plant densities was not large. Averaged over all $\mathrm{N}$ dressings, in the middle of July the WSC content in S2 was somewhat higher than in S1; at ripening (29/7) the average WSC content of S2 was about $2 \%$ higher than that of S1.

During the growing season from $27 / 5$ until $29 / 7$ a delay of the first $\mathbf{N}$ dressing caused a lower level of WSC production per unit area except for S1N1 (Fig. 8). At the lower plant density (S1) less WSC was found per unit area than at the higher plant density S2. For the last periodical harvest (29/7) this means that, on an average, there was also a higher reserve of WSC in the stems and leaves in S2.

\section{Discussion}

The 1980 growing season in the Netherlands was cool. The last week of April and the first three weeks of May were very dry and there was high radiation. Rainfall in 
the last week of May, in June and in July was high. $\mathrm{N}$ dressings in May had less effect on the development of the crop and on grain yield, because of the low quantity of precipitation. Moreover, the initially dry, but later wet and relatively cold weather must have adversely affected the availability of nitrogen from mineralization. Diez \& Sommer (1979) observed that during a cold period in April the soil layers contained a lower amount of mineral nitrogen than in the preceding and subsequent warmer spells. These authors also found a sharp decrease in mineral $\mathrm{N}$ from mineralization during a period of drought. The low level of mineralization, the low effectiveness of the nitrogen applied from GS 30 onwards and the relatively low temperature in that period, contributed to the total dry matter production remaining low, resulting in a lower grain yield. The direct relationship between total dry matter production per shoot at anthesis and grain yield was expressed by $r=0.74(P \leqslant$ 0.001). In pot experiments Rawson (1971) demonstrated a good correlation between the shoot weight at anthesis and the grain yield.

If for some reason the supply of nitrogen during the stage of stem elongation is not sufficient, fewer shoots will develop per $\mathrm{m}^{2}$ (Table 1). The competition for this nutrient is so great that only the dominant shoots will produce ears. Heyland \& Knopf (1980) also found that delaying the first N dressing (particularly from GS 31 or 32 and later) resulted in a clear reduction of number of ears per $\mathrm{m}^{2}$ and of ear weight, and thus of grain yield. Langer (1979) also found fewer shoots per plant when $\mathrm{N}$ was applied late. He found also that there was hardly any increase in number of grains per ear with late $\mathrm{N}$ application, whereas in our experiment there were more (Table 1). The time at which the first $\mathbf{N}$ dressing was applied (in our experiment between GS 22, and GS 45) determined the number of shoots per $\mathrm{m}^{2}$. When the number of shoots per $\mathrm{m}^{2}$ is plotted against the number of days the first $\mathrm{N}$ dressing is applied after GS 22 till stage 45, a negative correlation of $r=-0.64(P \leqslant 0.01)$ is found. Nitrogen shortage mainly inhibited the growth of higher-ranking tillers. The differences in yield in this experiment were mainly related to number of shoots per $\mathrm{m}^{2}$ (Table 1; Heyland \& Knopf, 1980; Simons, 1982). Also, 1000-grain weight (Table 1) and leaf area index (Ellen \& Spiertz, 1980) contributed to the yield differences.

The difference in number of plants per $\mathrm{m}^{2}$ largely affected the number of ears per plant. Due to this compensation, the differences in ear number per $\mathrm{m}^{2}$ were relatively small (Table 1). The number of ears per plant usually decreases rapidly when the number of plants per $\mathrm{m}^{2}$ is increased (Darwinkel, 1978; Puckridge \& Donald, 1967). The chances for survival of an individual shoot not only depend on the availability of sufficient nutrients and an adequate water supply, but also on its ability to intercept light in the period from ear initiation to anthesis. The space available for a tiller to growth within the crop is decisive for the tiller to produce an ear (Kirby \& Jones, 1977). Research done by Thorne (1982) suggests that from the stage of stem elongation the tillers act largely independently. If the growth regulator chlormequat is applied at the end of the tillering stage, the higher ranking tillers are able to continue their competition for light better. This will be favourable for the development of these tillers. This might explain why crops treated with chlormequat often produce more ears per $\mathrm{m}^{2}$ (Humphries, 1968). 
Although the average number of grains per ear was stimulated by delayed $\mathrm{N}$ dressings (Table 1), grain-filling did less well when the first $\mathrm{N}$ dressing was delayed. Heyland \& Knopf (1980) found fewer ears per $\mathrm{m}^{2}$ with more spikelets per ear, but with a lower grain yield per ear. Number of grains and grain yield per ear decreased from the main shoot to the youngest tiller. The time at which the shoot is initiated determines its potency (Fig. 2; Darwinkel, 1978). When plant density is higher, the weight and production per shoot are lower.

When at a moment shortly before anthesis the assimilation conditions change, for example because of an increase or decrease in radiation, the supply of carbohydrates to the ear may change as well. In our experiment a high radiation was measured during ear development stages. The advantage of this radiation on grainsetting for each shoot was greater the later the first $\mathrm{N}$ dressing was applied. In the plots with high plant densities and an early $\mathrm{N}$ dressing the late-formed tillers died at the time the main stems were heading. This phenomenon was not observed for low plant densities, as was also shown by Darwinkel (1978). In the latter case the light could penetrate further in the crop and therefore the late-developing tillers continued to photosynthesize and, consequently, the supply of assimilates to the ears of these tiller was maintained. Therefore the chances of survival increased, as well as did the fertility of the florets, as appeared from a higher number of grains per ear. In experiments of Fisher and Stockman (1980), a reduction in light shortly before anthesis led to a decline in fertility of the ear. The authors suggested that this was caused by a deficiency in assimilates. Experiments done by Willey \& Holliday (1971) demonstrated that shading of barley plants for some weeks before anthesis resulted in lower grain yields, mainly because of fewer shoots per $\mathrm{m}^{2}$ and fewer grains per ear. Slow development during a few weeks just before anthesis will probably increase the final yield, whereas rapid development dry matter production will decrease the final yield (Biscoe \& Gallagher, 1977).

The growing conditions for the main stem and the early initiated tillers are mostly more favourable than for the youngest tillers (Kemp, 1981). Not only are the latter later initiated, they also are lower situated; the competition for light is unfavourable, while the need for assimilates by these shoots is large, due to their rapid development. This frequently results in great differences between the ears (Rawson, 1971). Besides the moment of nitrogen fertilization, the rate at which reserve carbohydrates are stored is important. Gallagher et al. (1976) found evidence that at this early stage there is competition between ear growth and stem growth. The rate of shoot development will be faster in later initiated tillers (Fig. 2), because of their unfavourable location in the crop, more competition for radiation and the usually higher temperatures (Cannell, 1969). The growth of the tillers occurs in the same period that the ears develop. Growth rate in mg per shoot (6/5-17/6) and growth rate of the grains (17/6-29/7) were closely linked $(r=0.71 ; P \leqslant 0.001)$. Greater shoot weight before anthesis mostly results in a faster growth rate per ear because of a greater grain number per ear and not to a faster growth rate per grain. Grain growth rate per ear depends on weather conditions, the number of grains per ear (Table 1), on the availability of assimilates and on the variety (Dubois \& Fossati, 1981). Apart from being dependent on the supply of nutrients, grain growth per ear 
is affected by the size and quality of the leaf area. The dry matter production is determined (disregarding diseases) by radiation (Biscoe \& Gallagher, 1977), by the grains as sink for assimilates (King et al., 1967) and by the supply of nitrogen, minerals and water.

In our experiment there was a slight decrease in green leaf area from the onset of grain-filling (Fig. 1). The yellowing of the older leaves in the lower sections of the crop resulted in the weighi of the green leaf area decreasing only slightly up to the moment at which the colour of the grain started to turn from green to yellow (15/7). At that time the senescence of the leaves accelerated. The photosynthesis of these leaves then ceases (Vos, 1981). When all green leaves have died, the grain filling is almost complete. The last part of the grain-filling process is therefore achieved by a redistribution of the assimilates from the various plant parts (Spiertz, 1977; Spiertz \& Ellen, 1978).

The effect of a delay of the first $\mathrm{N}$ dressing on the specific dry matter weight of the green leaves varied. No clear trend emerged from the various periodical harvests either. Darwinkel (1983) found clear differences in the specific leaf weight (SLW) in conditions similar to those prevailing in our experiment. The differences in this respect that he observed between main stem and tillers depended on tiller initiation and were also observed in our experiment. The SLW from the main stem to the $3 \mathrm{rd}$ tiller, averaged over all $\mathrm{N}$ dressings ranged from $6.03 \mathrm{mg} / \mathrm{cm}^{2}$ to $5.45 \mathrm{mg} / \mathrm{cm}^{2}$ for $\mathrm{S} 1$, and the SLW from the main stem to the second tiller in S2 ranged from $5.77 \mathrm{mg} / \mathrm{cm}^{2}$ to $4.94 \mathrm{mg} / \mathrm{cm}^{2}$, in the period $27 / 5-15 / 7$. In field experiments with more varieties Herzog (1980) found values that were somewhat lower, but in a greenhouse experiment Herzog (1982) observed values of SLW, that were about half as we measured in our experiment. Plant density (regarding to the ability to intercept light), variation in radiation (leading to a higher or lower production of assimilates), and the supply of nutrients and water all play an important role in fixing the specific dry matter weight of the leaves. Leaves that have grown in an environment with less light will, to a certain extent, meet the qualities of shaded leaves. This means that even with sufficient light they may have a low $P_{\max }$ (= net photosynthetic capacity) and a relatively small reserve of water-soluble carbohydrates (WSC) that is available for transport. Periods of relatively little light and much redistribution of WSC to the developing grains can result in stems and leaves of the late-formed shoots having a low WSC content (Ellen, unpublished).

The nitrogen content of the plant is largely determined by the time of $\mathbf{N}$ dressing (Fig. 5). A rapid uptake of nitrogen can be achieved in various ways. First of all, the transpiration stream later in the season is larger because then the leaf area is larger, the temperature is higher and the root system of the plants is larger.

During the season the sink for $\mathrm{N}$ in growing plants becomes greater; firstly caused by a rapid growth of stems and leaves, later caused by grain growth. Beyond this increasing $\mathrm{N}$ demand, the availability of nitrogen from the second nitrogen dressing and from mineralization in the soil will explain the considerable increase of the nitrogen uptake, continuing until mid-July. Delayed $\mathrm{N}$ dressing lead to a rapid and a same $\mathrm{N}$ uptake (Heyland \& Knopf, 1980). Because dry matter yield lagged somewhat behind (Table 1), $\mathrm{N}$ content in the aerial parts of the plants and probably 


\section{J. ELLEN}

also in the roots were higher. In our experiment a decrease in the nitrogen content of the grains was observed mainly in the period of milk-ripeness. During the dough stage, the content increased again. The increase of nitrogen, taken up after redistribution, was relatively larger than the increase of dry matter yield. Due to an equivalent withdrawal of dry matter and nitrogen the nitrogen content in the vegetative plant parts remained practically stable. The differences between the dates of fertilization also remained.

\section{Acknowledgements}

The author is grateful to Dr B. Deinum, Professor L. J. P. Kupers, Dr J. H. J. Spiertz and Professor G. J. Vervelde for their valuable comments, and to $\mathrm{Mr}$ J. S. de Block for translating the manuscript.

\section{References}

Biscoe, P. V. \& J. N. Gallagher, 1977. Weather, dry matter production and yield. In: J. J. Landsberg \& C. V. Cutting (Eds.), Environmental effects on crop physiology. Academic Press, New York, London, $75-100$.

Cannel, R. Q., 1969. The tillering pattern in barley varieties. II. The effect of temperature, light intensity and daylength on the frequency of occurrence of the coleoptile node and second tillers in barley. Journal of Agricultural Science, Cambridge 72: 423-435.

Darwinkel, A., 1978. Pattern of tillering and grain production of winter wheat at a wide range of plant densities. Netherlands Journal of Agricultural Science 26: 393-398.

Darwinkel, A., 1983. Ear formation and grain yield of winter wheat as affected by time of nitrogen supply. Netherlands Journal of Agricultural Science 31: 211-225.

Diez, Th. \& G. Sommer, 1979. Veränderungen des Gchaltes an löslichem Bodenstickstoff (Nmin) im Jahresablauf. Bayerisches Landwirtschaftliches Jahrbuch 56(1) 351-363.

Dilz, K., 1969. Stikstofhoeveelheden, gedeelde stikstofgiften en CCC op wintertarwe. Stikstof 61: 1114.

Dubois, J.-B. \& A. Fossati, 1981. Influence of nitrogen uptake and nitrogen partitioning efficiency on grain yield and grain protein concentration of twelve winter wheat genotypes (Triticum aestivum L.). Zeitschrift für Pflanzenzüchtung 86: 41-49.

Ellen, J. \& J. H. J. Spiertz, 1975. The influence of nitrogen and Benlate on leaf-area duration, grain growth and pattern of N, P and K-uptake of winter wheat (Triticum aestivum). Zeitschrift für Ackerund Pflanzenbau, 141: 231-239.

Ellen, J. \& J. H. J. Spiertz, 1980. Effects of rate and timing of nitrogen dressings on grain yield formation of winter wheat (Triticum aestivum). Fertilizer Research 1: 177-190.

Fischer, R. A. \& Y. M. Stockman, 1980. Kernel number per spike in wheat (Triticum aestivum L.): Responses to anthesis shading. Australian Journal of Plant Physiology 7: 169-180.

Gallagher, N., P. V. Biscoe \& R. K. Scott, 1976. Barley and its environment. VI. Growth and development in relation to yield. Journal of Applied Ecology 13: 563-583.

Herzog, H., 1980. Source- und Sink-Verhaltnis während der Kornfüllingsperiode bei sechs Winterweizensorten. Zeitschrift für Acker- und Pflanzenbau 149: 472-487.

Herzog, H., 1982. Grain development and temporary dry matter storage in vegetative organs of wheat genotypes. Zeitschrift für Acker- und Pflanzenbau 151: 388-398.

Heyland, K. U. \& H. E. Knopf, 1980. N-Angebot und N-Aufnahme und ihr zeitlicher Bezug zur Ertragsbildung von Winterweizen und Wintergerste. Bayerisches Landwirtschaftliches Jahrbuch 57(3) 359-375.

Humphries, E. C., 1968. The beneficial effect of CCC on wheat yields in dry conditions. Euphytica Supplement 17: 274-281. 
Kemp, D. R., 1981. Comparison of growth rates and sugar and protein concentrations of the extension zone of main shoot and tillers of wheat. Journal of Experimental Botany 32 (126) 151-158.

King, J. W., I. F. Wardlaw \& L. T. Evans, 1967. Effect of assimilate utilization on photosynthetic rate in wheat. Planta, Berlin 77: 261-276.

Kirby, E. J. M. \& H. G. Jones, 1977. The relations between the main shoot and tillers in barley plants Journal of Agricultural Science, Cambridge 88: 381-389.

Langer, T. H. M., 1979. The dynamics of wheat yield. Wheat Review 14 (1977-1979) 32-40.

McLaren, J. M., 1981. Field studies on the growth and development of winter wheat. Journal of Agricultural Science, Cambridge 97: 685-697.

Oosterhuis, D. M. \& P. M. Cartwright, 1983. Spike differentiation and floret survival in semidwarf spring wheat as affected by water stress and photoperiod. Crop Science 23: 711-717.

Puckridge, D. W. \& C. M. Donald, 1967. Competition among wheat plants sown at a wide range of densities. Australian Journal of Agricultural Research 18: 193-211.

Rawson, H. M., 1971. Tillering patterns in wheat with special reference to the shoot at the coleoptile node. Australian Journal of Biological Science 24: 829-841.

Simons, R. G., 1982. Tiller and ear production of winter wheat. Field Crop Abstracts 35: 857-870.

Sofield, I., L. T. Evans, M. G. Cook \& I. F. Wardlaw, 1977. Factors influencing the rate and duration of grain filling in wheat. Australian Journal of Plant Physiology 4: 785-795.

Spiertz, J. H. J., 1977. The influence of temperature and light intensity on grain growth in relation to the carbohydrate and nitrogen economy of the wheat plant. Netherlands Journal of Agricultural Science 25: $182-197$.

Spiertz, J. H. J. \& J. Ellen, 1978. Effects of nitrogen on crop development and grain growth of winter wheat in relation to assimilation and utilization of assimilates and nutrients. Netherlands Journal of Agricultural Science 26: 210-231.

Thorne, G. N., 1982. Distribution between parts of the main shoot and the tillers of photosynthate produced before and after anthesis in the top three leaves of main shoots of Hobbit and Maris Huntsman winter wheat. Annals of Applied Biology 101: 553-559.

Vos, J., 1981. Effects of temperature and nitrogen supply on post-floral growth of wheat; measurements and simulations. Agricultural Research Report No 911 Pudoc, Wageningen, $164 \mathrm{pp}$.

Whingwiri, W. W. \& D. R. Kemp, 1980. Spikelet development and grain yield of the wheat ear in response to applied nitrogen. Australian Journal of Agricultural Research 31: 637-647.

Willey, R. W. \& R. Holliday, 1971. Plant production and shading studies in barley. Journal of Agricultural Science, Cambridge 77: 445-452.

Zadoks, J. C., T. T. Chang \& C. F. Konzak, 1974. A decimal code for growth stages of cereals. Weed Research 14: 415-421. 